\begin{tabular}{|c|c|c|c|c|c|c|}
\hline \multirow{4}{*}{ Impact Factor: } & ISRA (India) & $=3.117$ & SIS (USA) & $=0.912$ & ICV (Poland) & $=6.630$ \\
\hline & ISI (Dubai, UAE & $=0.829$ & РИНЦ (Russia) & $=0.156$ & PIF (India) & $=1.940$ \\
\hline & GIF (Australia) & $=0.564$ & ESJI (KZ) & $=8.716$ & IBI (India) & $=4.260$ \\
\hline & JIF & $=1.500$ & SJIF (Morocco & $=5.667$ & OAJI (USA) & $=0.350$ \\
\hline
\end{tabular}

\section{SOI: $1.1 /$ TAS DOI: $10.15863 /$ TAS International Scientific Journal Theoretical \& Applied Science}

p-ISSN: 2308-4944 (print) e-ISSN: 2409-0085 (online)

Year: $2019 \quad$ Issue: $05 \quad$ Volume: 73

Published: $30.05 .2019 \quad \underline{\text { http://T-Science.org }}$

UDK 329.058.1
QR - Issue

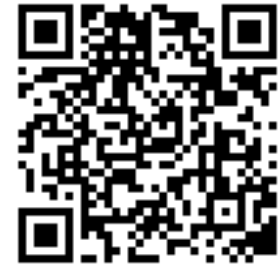

Sirojjon Nasipkulovich Berdikulov doctor of philosophy, associate Professor Head of the Department of Legal Disciplines of the Academy of the Ministry of Internal Affairs of the

Republic of Uzbekistan siroj-berdikulov@rambler.ru

\title{
MULTIPARTY SYSTEM AND DEVELOPMENT OF ITS NATIONAL MODEL IN UZBEKISTAN
}

Abstract: Multiparty system is paid special attention to in process of developing civil society and deepening democratic reforms in the republic of Uzbekistan. Because rights and interests of citizens of the country are ensured by this system, problems which appear in the society are solved reasonably. According to this point of view, the author expresses his opinion that multiparty system is difference for its democratic aspects about. Making his suggestions, recommendation and conclusions on development of multiparty system in Uzbekistan, he gives a description of authorship about a notion of multiparty system.

Key words: political parties; multiparty system; civil society; electorate; democracy; political pluralism; national model; political institution.

Language: English

Citation: Berdikulov, S. N. (2019). Multiparty system and development of its national model in Uzbekistan. ISJ Theoretical \& Applied Science, 05 (73), 389-391.

Soi: http://s-o-i.org/1.1/TAS-05-73-58 Doi: crossef https://dx.doi.org/10.15863/TAS.2019.05.73.58

\section{Introduction:}

Establishment of multiparty system in Uzbekistan is once more evidence that the country has chosen a peculiar way. Multiparty system plays a main role in expressing interests of election in the society, ensuring diversity of thoughts. At the same time, multiparty system includes rights and interests of citizens of the country within their ideology in difference of other forms of party systems. Proceeding from this point of view, multiparty system and problem of its place in the society is notable for today with its urgency.

Main part: formation and development of multiparty system

Generally speaking, today forms of multiparty system began to appear at the end of the XVII century and at the beginning of the XVIII century. As a negative relation exited against the parties in that period, there was a predominant opinion that they divided into members of the society instead of joining, uniting them, defending interests of a separate group. For example, if George Washington has given a description of parties as for they have been «ready gun» in order to overturn government of people and take away the authority in his «A letter of farewell» to people of America on dangerous consequence of «party spirit» [5, p.283-284], Alexis de Tocqueville said that «the parties are unavoidable trouble to lead free governments to crisis» [6, p.144], T. Gobs expressed his idea that «the parties are organizations which think in criminal with respect to a state» [8, p.105]. Oppositely to these ideas, the thinkers such as F. Beckons, E. Berks, and N. Machiavelli expressed their benevolent opinions for active part of some parties in the society. For example, if the English philosopher E. Berks expressed his opinion about that «the parties which were organization of men, must be made up in order to defend national interests» [4, p.10], a political scholar and historian N. Machiavelli thinks that «Even they are useful, so maybe citizens «learn to save unity» «analyzing destructive experience of the others» (they have tested hostilities and conflicts raised by parties)» [5, p. 284]

In view of period, it is possible to connect appearance of the multiparty system with establishment of a middle layer and private property in society. As the private property has given great opportunity and conditions to representatives of the middle layer, different social interests and needs appeared in society. First of all, groups, unions later political parties came into existence in order to satisfy 


\begin{tabular}{|c|c|c|c|c|c|c|}
\hline \multirow{4}{*}{ Impact Factor: } & ISRA (India) & $=3.117$ & SIS (USA) & $=0.912$ & ICV (Poland) & $=6.630$ \\
\hline & ISI (Dubai, UAI & $=0.829$ & РИНЦ (Russia & $=0.156$ & PIF (India) & $=1.940$ \\
\hline & GIF (Australia) & $=0.564$ & ESJI (KZ) & $=8.716$ & IBI (India) & $=4.260$ \\
\hline & JIF & $=1.500$ & SJIF (Morocce & $=5.667$ & OAJI (USA) & $=0.350$ \\
\hline
\end{tabular}

those interests and needs. Mutual relation of some political parties in society led to develop the multiparty system.

Really, appearance of the multiparty system in society is peculiarity to civil society. Interests, needs and aims of groups, layers, estates which are operating in society show up clearly. Appearance of the multiparty system, ascertainment of constructive dialogue between political parties and different groups and also tendencies in society, giving them legal equal rights and chances, existence of democratic principles and values in social-political processes will serve to develop civil society and to strengthen constructive competition between parties in the country. As well any party in the multiparty system is not given preponderance, but a definite party collected a majority as an election has an opportunity to form a government.

R. Aron affirms: «Authority is realized by the constitutional way in the multiparty system. Carrying on the multiparty system and constitutional method together specifies principle problems before the regime. The multiparty system is a legatee of constitutional and liberal systems in view of history. It is characteristic feature to try keeping liberal values in condition of policy of democratizing: it is necessary that the government has power to the right degree to operate effectively; it is made up within constitution keeping rights of citizens. Dialect of the multiparty system is dialect of liberalism and democracy, democracy and efficiency ...It is necessary to save to be ensured efficiency of state authority and observance to constitution in spite of storms of passions and collision of interests in the multiparty system, society» [1]. So, if it is not kept to constitution and orders in the country where the multiparty system was established, the anarchy will be result there. And it causes a political crisis in the country. It is being paid special attention to observe the constitution and laws in the process of development of multiparty system in Uzbekistan on the contrary of this event. «Only in case of establishing multiparty system in the political order, the state can express people's interests and make up solid basis of stability in the society» [3].

Particularly, an approach is being carrying as a civil society, principles of legal, democratic state with respect to multiparty system. Therefore, securing social stability as a result of legal activity, keeping equilibrium between in a society, realizing goals and tasks in their program are considered main norm of multiparty system.

M. Duverger said in his titled «Political parties» that «Though order of multiparty has some deficiencies, it has advantages than an order of a single party» [3] or French politician J.Besler explains that «If there is multiparty system in a society, political parties will control each other. Democracy is considered stability if there are two parties or more than them in a society. So, a political struggle between parties ensures efficiency of power and its stability. A single party system is considered a ruling society bit not democratic one. Even ruling a power by a party leads to infringe up democracy for long time» $[2$, p.117]. Consequently, appearance of multiparty system for social-political development of a society, formation of it from «low» not from «above» yields effective results.

Available of multiparty system in society ensures that democratic principles and values have important significance in social-political life and democratic progress in the country. At the same time, it is not right to realize that multiparty system is organization averting all negative defects in a society and settling different dangers. Multiparty system is not guarantee to develop a society absolutely but it creates it condition.

After Uzbekistan obtained independence, the process of transition from a single party system to multiparty system took place. Equal legal conditions are created for political parties operating in the country, environment of constructive competition develop between them, and free realization of desire of voters is secured to elect officials of State power. Therefore, multiparty system is a concept ensuring competition between parties for State power, expressing collection of political-legal mechanisms. It has practical significance that parties really support interests of their election in multiparty system. As well as multiparty system causes political pluralism through support of interests and needs of various social groups. But the political pluralism is considered an essential factor to develop multiparty system. For this reason, development of multiparty system has been specified in the twelfth article of the constitution of the republic of Uzbekistan «Social life in the republic of Uzbekistan is on the basis of diversity of political institutions, ideologies, thoughts». And it gives great chance to develop national model of multiparty system in the republic.

\section{Conclusion:}

If we make conclusion, firstly, national model of multiparty system was created in Uzbekistan.

Secondly, multiparty system embraces rights and interests of citizens living in the country as distinct from other kinds of party systems.

Thirdly, when political parties are struggling for a definite idea in a society, they begin mutual relation in the process and create multiparty system.

Fourthly, establishing of monopoly of a single ruling party in a society damages progress of the country, for this reason multiparty system in Uzbekistan is considered suitable state.

Fifthly, illegal actions are removed as a result of establishing of multiparty system, strengthening constructive dialogue between political parties, various groups and tendencies in the society, creating legal equal rights and possibilities for them, available 


\begin{tabular}{|c|c|c|c|c|c|c|}
\hline \multirow{4}{*}{ Impact Factor: } & ISRA (India) & $=3.117$ & SIS (USA) & $=0.912$ & ICV (Poland) & $=6.630$ \\
\hline & ISI (Dubai, UAE & $=0.829$ & РИНЦ (Russia & $=0.156$ & PIF (India) & $=1.940$ \\
\hline & GIF (Australia) & $=0.564$ & ESJI (KZ) & $=8.716$ & IBI (India) & $=4.260$ \\
\hline & JIF & $=1.500$ & SJIF (Morocce & $=5.667$ & OAJI (USA) & $=0.350$ \\
\hline
\end{tabular}

of democratic principles and values in the socialpolitical processes.

Sixth, multiparty system is not bound up with registering of some parties in a society and their activity. Proceeding from this, we can make a conclusion that multiparty system is an idea ensuring competition between parties for State power, expressing collection of political-legal mechanisms.
Generally speaking, determining factors that multiparty system in the society has important significance include to be supported them by citizens, in its turn, activity of parties in realization of interests of citizens, to make decisions on main goals and tasks connected with vital interests of a state and a society. While becoming important civil institute, the political parties operating in the country are maintaining that multiparty system is objective social necessity.

\section{References:}

1. Aron, R. (n.d.). Democracy and totalitarian regime. Retrieved 2019, from http://www.biblioclub.ru/book/26468/

2. Beshler, J. (1994). Democracy. (p.117). Moscow. (in Russian).

3. Duverje, M. (n.d.). Political parties. Retrieved 2019, from http://bookz.ru/authors/duverjemoris/duverje_m01.html (in Russian).

4. Juraev, K. (1999). Kuppartiyaviylik demokratik taraqqiyot omili. (p.10). Tashkent: UWED. (in Uzbek).
5. Pugachev, V. P., \& Solovev, A. I. (2004). Siyosatshunoslikka kirish. (p.284). Tashkent: Yangi ast avlodi. (in Uzbek).

6. Tokvil, A. (1992). Demokratiya v Amerike: Translation from French/ Preface Garold Ge. Laski. (p.144). Moscow: Progres. (in Russian).

7. (2018). The constitution of the republic of Uzbekistan. (p.6). Tashkent: Uzbekiston. (in Uzbek).

8. Kirgizboev, M. (2003). Fuqarolik jamiyati: nazariya va xorijiy tajriba. (p.105). Tashkent: Yangi ast avlodi. (in Uzbek). 
ISRA (India) $\quad \mathbf{=} \mathbf{3 . 1 1 7}$

Impact Factor: $\quad$ ISI (Dubai, UAE) $=\mathbf{0 . 8 2 9}$

GIF (Australia) $=\mathbf{0 . 5 6 4}$

JIF

$=1.500$
SIS (USA)

РИНЦ $($ Russia $)=0.156$

$\mathrm{ESJI}(\mathrm{KZ}) \quad=\mathbf{8 . 7 1 6}$

SJIF $($ Morocco $)=\mathbf{5 . 6 6 7}$
ICV (Poland)

PIF (India)

IBI (India)

$=6.630$ 